\title{
Anatomy of melancholy
}

Howard Gardner

An Unquiet Mind: A Memoir of Moods and Madness. By Kay Redfield Jamison: Knopf: 1995. Pp. 240. $\$ 22$

THIs first-person account of manic-depressive illness is a riveting read. I devoured it at a single sitting and found the book almost as compelling on a second reading a month later. To anyone unfamiliar with this frightening disorder, which leads to the death of thousands of people annually, I can recommend this book without hesitation. And it also harbours dividends for those in search of fresh insights into what has come to be called bipolar disorder.

Kay Redfield Jamison led a comfortable, almost storybook childhood in the Washington DC area in the 1950 s. Her first inkling that she might not be completely in her right mind came after she moved to California as a teenager. At about the time that her father began to behave strangely and her parents' marriage slowly unravelled, Jamison felt unhappy and alienated from her peers and her surroundings. She "soared" and "crashed" repeatedly in college - oscillating between incredible energetic heights and profound despair with her life - but made it through nonetheless. Discovering that her passion was psychology, she proceeded by a fairly direct route to graduate school, a first marriage, a doctorate in clinical psychology and a job as a junior professor at the University of California at Los Angeles. As she declares: "Within three months of becoming a professor, I was ravingly psychotic".

The heart of Jamison's book is a description of her bouts of madness over the next 15 years. It is a chilling story. Despite her interest as a professional in manic-depressive disorders and despite exhibiting textbook symptoms, the youthful scientist goes to great lengths to deny that she is desperately ill. She launches wild physical and mental adventures, embarks on crazy spending sprees, experiences hallucinations of catastrophes, has horrible bouts of depression, hurts those whom she loves and who love her, flirts with various forms of suicide and almost succeeds in killing herself through a massive drug overdose. Prescribed lithium, the one drug tailormade for her disorder, she refuses to remain on the treatment course - in part through a continuing denial, in part through a nostalgia for her exhilarating manic flights, in part for fear that if lithium should somehow fail her, she will know for sure that she is doomed.

Jamison's story has a reassuring, happy ending. Her professional career continues to be crowned with success - indeed, her reputation is made through the study of the very disorder that she and close family members have inherited. She eventually accepts her illness and is able to control it with medication. She benefits as well from skilled psychotherapy. Most important from her point of view, the support of individuals who love her without restriction, and from colleagues who accept her despite her admitted disease, allows her to achieve peace. In a startling confession, she in fact admits that, if given the choice, she would choose manic-depressive disease over its absence - but only if the disease could be controlled by medication. Although she is occasionally nostalgic for the thrill of unalloyed mania, she concludes: "The current longings are, for the most part, only longings, and I do not feel compelled to re-create the intensities: the consequences are too awful, too final, and too damaging".

For lay readers, An Unquiet Mind may well become a classic, taking its place alongside such poignant memoirs as William Styron's account of depression, Darkness Visible, or M. A. Sechehaye's Autobiography of a Schizophrenic Girl. More scientific readers may be a bit disappointed, because Jamison skates only lightly over the psychiatric literature, with the briefest discussions of diagnostic categories, the genetic basis of bipolar disease, and the neuropharmacology of treatment. I for one missed an analysis of the contributions - good and bad - of this peculiar disorder to the creative process. Who could be a more authoritative witness than Jamison, who is at once an eminent scientific researcher and a skilled, at times poetic, literary artist? And yet it is not fair to criticize Jamison on these accounts. This is not a book for the specialist; those of us who wish to probe more deeply need only look into Jamison's own accounts of creativity and madness in Touched with Fire (1993) or her well-regarded medical text Manic Depressive Illness (1990).

Nevertheless, this popular account speaks as well to those of us with a scientific or professional interest in manic depressive diseases.
In baring her medical soul, Jamison sets an example of courage; she knows that some will question her science and others her motives. She reminds us of how difficult it is for even the most respected professional to confront the possibility that he or she may be seriously ill and need proper treatment: not even those with supposedly special insights into the mind are spared. She gives an excellent account of the way in which an appropriate course of drugs, in combination with prompt and sensitive therapy, can be of far greater benefit than either could alone. Revealingly, she emphasizes the tremendous importance of that least quantifiable of entities - 'love'. Jamison tells us that she would not be here today were it not for the often remarkable and unquestioned love that she received from others; and, more disquietingly, she reveals how a lack of love, an unkind comment, even a disapproving look, can devastate an individual who feels vulnerable.

Jamison is not just writing about 'others': when she marshals the courage to tell her new supervisor about her illness, he has the grace to laugh and say: "If we got rid of all of the manic-depressives on the medical school faculty, not only would we have a much smaller faculty, it would also be a far more boring one".

Howard Gardner is at the Graduate School of Education, Harvard University, 201 Larsen Hall, Appian Way, Cambridge, Massachusetts 02138, USA.
The Three Ages and Death by Hans Baldung Grien.The picture is reproduced in Aging: A Natural History by Robert E. Ricklefs and Caleb E. Finch. The authors, leading workers in the physiological and evolutionary approaches to gerontology, provide an up-to-date and well-illustrated account of all aspects of the field that, like other volumes in the Scientific American Library series, will appeal to laypeople and specialists alike. W. H. Freeman/ Scientific American Library, \$32.95, $£ 19.95$.

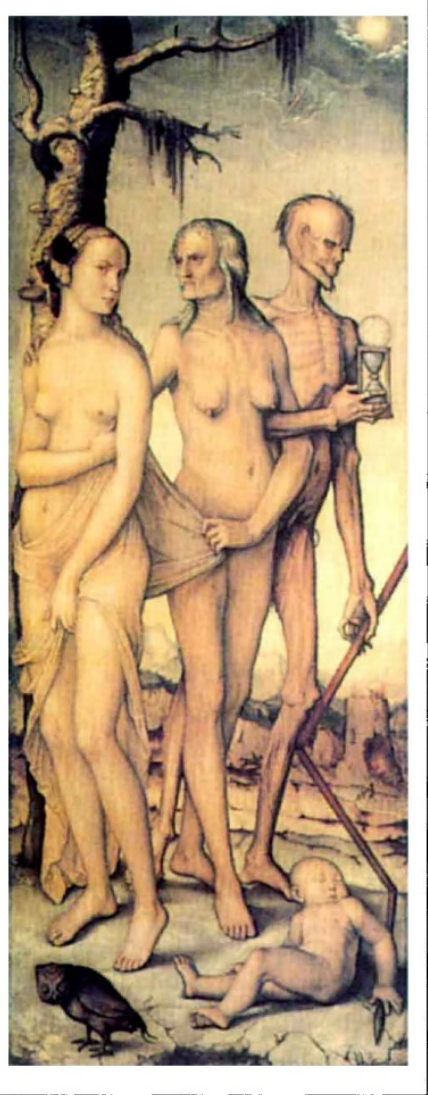

